\title{
FACTORS AFFECTING CELLULASE PRODUCTION BY TRICHODERMA KONINGII
}

\author{
F. I. EL-HAWARY and Y. S. MOSTAFA
}

Microbiology Department, Faculty of Agriculture, Mansoura University, Mansoura. Egypt

(Received: 22 November 1999; revision received: 5 June 2000; accepted: 29 August 2000)

Because of the need for renewable energy resources, cellulose, which can be enzymatically hydrolyzed to glucose, has drawn lot of attention during the past decade. However, the process of cellulose conversion using cellulase is not yet economically feasible because of the high cost of enzymes. Factors influencing the cellulase production of Trichoderma koningii using both acid and steam treated sugar cane bagasse and rice straw as carbon sources were investigated. The highest levels of cellulase activities were obtained using a culture medium containing urea and $\left(\mathrm{NH}_{4}\right)_{2} \mathrm{SO}_{4}$ together as nitrogen sources at $0.217 \%$ and $0.241 \%$ for both carbon sources. When the culture medium was supplemented either with $0.5 \%$ Tween 60 or Tween 80 , the rate of cellulase production was increased considerably. Maximum levels of both filter paper and CMC-ase activities produced on both media were obtained at $25^{\circ} \mathrm{C}$ and 100 r.p.m., while the highest level of $\beta$-glucosidase production was obtained at $30^{\circ} \mathrm{C}$ and 200 r.p.m.

Keywords: cellulase production, sugar cane bagasse, rice straw, pretreatment

There has been a continuously increasing interest towards the saccharification of cellulosic waste materials by enzymes in recent years (ENAYATI \& PARULEKAR, 1995). The enzymatic conversion of native cellulose is catalyzed by the synergistic action of enzymes including endo- $\beta$-1,4-glucanase (EC 3.2.1.4), cellobiohydrolase (EC 3.2.1.91), and $\beta$-glucosidase (EC 3.2.1.21). These enzymes are synthesized by a large variety of microorganisms including fungi and bacteria as well. However, fungal species have been more intensively studied because they produce extracellular cellulases.

Due to the low specific activity of cellulases, a large quantity of enzyme per unit amount of substrate is required to obtain high conversion yield of cellulose. An important obstacle in the exploitation of lignocellulosics is the rather costly production of cellulases contributing as much as $50 \%$ of the overall cost of saccharification process (MANDELS, 1985). Furthermore, microbial synthesis of cellulase enzymes is subjected to catabolite repression, and it has to be induced by cellulose. In the present study, the production of cellulolytic enzyme system of $T$. koningii using two different carbon 
sources, i.e. acid and steam treated sugar cane bagasse and rice straw was examined. Various factors, such as quality and concentration of nitrogen source; addition of surfactants; incubation temperature as well as agitation speed, were studied in order to optimize the cellulase production of $T$. koningii.

\section{Materials and methods}

\subsection{Microorganism}

Freeze-dried spore preparation of Trichoderma koningii 2691 was obtained from the National Collection of Agricultural and Industrial Microorganisms (NCAIM), Budapest, Hungary. The fungal stock culture was maintained on PDA slants medium at $4{ }^{\circ} \mathrm{C}$.

\subsection{Enzyme production}

The growth and production medium (TÜRKER \& MAVITUNA, 1987) contained $7 \mathrm{~g} \mathrm{l}^{-1}\left(\mathrm{NH}_{4}\right)_{2} \mathrm{SO}_{4}, 10 \mathrm{~g} \mathrm{l}^{-1} \mathrm{KH}_{2} \mathrm{PO}_{4}, 1.5 \mathrm{~g} \mathrm{l}^{-1} \mathrm{MgSO}_{4} \cdot 7 \mathrm{H}_{2} \mathrm{O}, 1.5 \mathrm{~g} \mathrm{l}^{-1} \mathrm{CaCl}_{2} \cdot 2 \mathrm{H}_{2} \mathrm{O}$, $1.5 \mathrm{~g} \mathrm{l}^{-1}$ urea, $1 \mathrm{~g} \mathrm{l}^{-1}$ glucose. The medium was supplemented with trace elements: $25 \mathrm{mg} \mathrm{l}^{-1} \quad \mathrm{FeSO}_{4} \cdot 7 \mathrm{H}_{2} \mathrm{O}, \quad 10.3 \mathrm{mg} \mathrm{l}^{-1} \quad \mathrm{MnSO}_{4} \cdot 4 \mathrm{H}_{2} \mathrm{O}, 7 \mathrm{mg} \mathrm{l}^{-1} \quad \mathrm{ZnSO}_{4} \cdot 7 \mathrm{H}_{2} \mathrm{O}$ and $18.3 \mathrm{mg} \mathrm{l}^{-1} \mathrm{CoCl}_{2} \cdot 6 \mathrm{H}_{2} \mathrm{O}$. Steam pretreatment of both sugar cane bagasse and rice straw was carried out according to CARRASCO (1994) at $120^{\circ} \mathrm{C}$ for $100 \mathrm{~min}$ in the presence of $1 \%$ sulfuric acid. Pretreated sugar cane bagasse and rice straw were used as carbon sources. The production medium contained $1.5 \%$ of carbon source. A $3 \mathrm{ml}$ spore suspension obtained from 7-d PDA slant culture was used to initiate growth in a shake flask containing $50 \mathrm{ml}$ of sterile culture medium at $\mathrm{pH} 5.0$. Cultures were incubated on a rotary shaker at 100 r.p.m. and $30^{\circ} \mathrm{C}$. The fermentation broth was harvested then filtered and analyzed for various enzyme activities.

\subsection{Assays}

Filter paper activity (FPA) was measured according to MANDELS and co-workers (1976) procedure. The reaction mixture containing $0.5 \mathrm{ml}$ of $0.05 \mathrm{M}$ acetate buffer $(\mathrm{pH}$ $4.8)$ and $0.5 \mathrm{ml}$ of culture filtrate was incubated together with a $1 \times 3 \mathrm{~cm}(25 \mathrm{mg})$ strip of Whatman No. 1 filter paper at $50^{\circ} \mathrm{C}$ for $60 \mathrm{~min}$. The enzymatic reaction was terminated by addition of $1 \mathrm{ml}$ DNS reagent (MILLER, 1959). After $5 \mathrm{~min}$ of boiling and addition of $10 \mathrm{ml}$ distilled water the absorbance was measured at $540 \mathrm{~nm}$. 
Carboxyl-methyl-cellulose degrading capacity (CMC-ase) was determined by incubating $0.5 \mathrm{ml}$ of enzyme sample together with $0.5 \mathrm{ml}$ of $1 \%$ carboxy-methylcellulose in $0.05 \mathrm{~mol}^{-1}$ acetate buffer $(\mathrm{pH} 4.8)$ at $50^{\circ} \mathrm{C}$ for $30 \mathrm{~min}$. The hydrolysis was stopped by addition of $1 \mathrm{ml}$ DNS reagent. After boiling for $5 \mathrm{~min}$ and dilution with 10 $\mathrm{ml}$ of distilled water the absorbance was read at $540 \mathrm{~nm}$.

For $\beta$-glucosidase activity determination $10 \mu \mathrm{l}$ of culture filtrate was incubated together with $1 \mathrm{ml}$ of $0.67 \mathrm{mmol}^{-1}(0.02 \%)$ p-nitrophenyl- $\beta$-D-glucopyranoside in $0.05 \mathrm{~mol} \mathrm{l}^{-1}$ acetate buffer $(\mathrm{pH} 4.8)$ ad $50^{\circ} \mathrm{C}$ for $10 \mathrm{~min}$. The enzymatic reaction was terminated by addition of $3 \mathrm{ml} 0.1 \mathrm{~mol} \mathrm{l}^{-1} \mathrm{NaOH}$ solution. The absorbance was measured at $400 \mathrm{~nm}$ (RÉCZEY et. al., 1990).

\section{Results and discussion}

\subsection{The effect of nitrogen source}

The effect of alternative nitrogen sources on the production of cellulolytic enzymes using two different media was investigated. Ammonium sulfate and urea of basal medium were replaced with urea or ammonium sulfate separately or with other organic and inorganic nitrogen sources is such amounts that the final nitrogen concentration in the media remained unchanged. The results are summarized in Fig. 1. It can be seen that the highest enzyme activities were obtained when the original culture medium was used in which both urea and $\left(\mathrm{NH}_{4}\right)_{2} \mathrm{SO}_{4}$ were added. With all other nitrogen sources considerably lower activities were obtained.

These findings were in good agreement with the results obtained by MANDELS and WEBER (1969) and TÜRKER and MAVITUNA (1987). It was also observed that using urea or $\left(\mathrm{NH}_{4}\right)_{2} \mathrm{SO}_{4}$ separately resulted in much lower cellulase production, which could be due to $\mathrm{pH}$ changes during the cultivation. The final $\mathrm{pH}$ of the culture broth was more acidic when ammonium containing compounds were added to the medium compared to urea or other organic nitrogen sources. This observation was in good agreement with HAAPALA and co-workers $(1994,1996)$. They showed that the deamination of urea resulted in increasing $\mathrm{pH}$ in the culture medium.

\subsection{The effect of nitrogen source concentration}

The effect of various concentrations of urea and ammonium sulfate as nitrogen sources on the cellulase production was also investigated. The results are plotted in Fig. 2. 


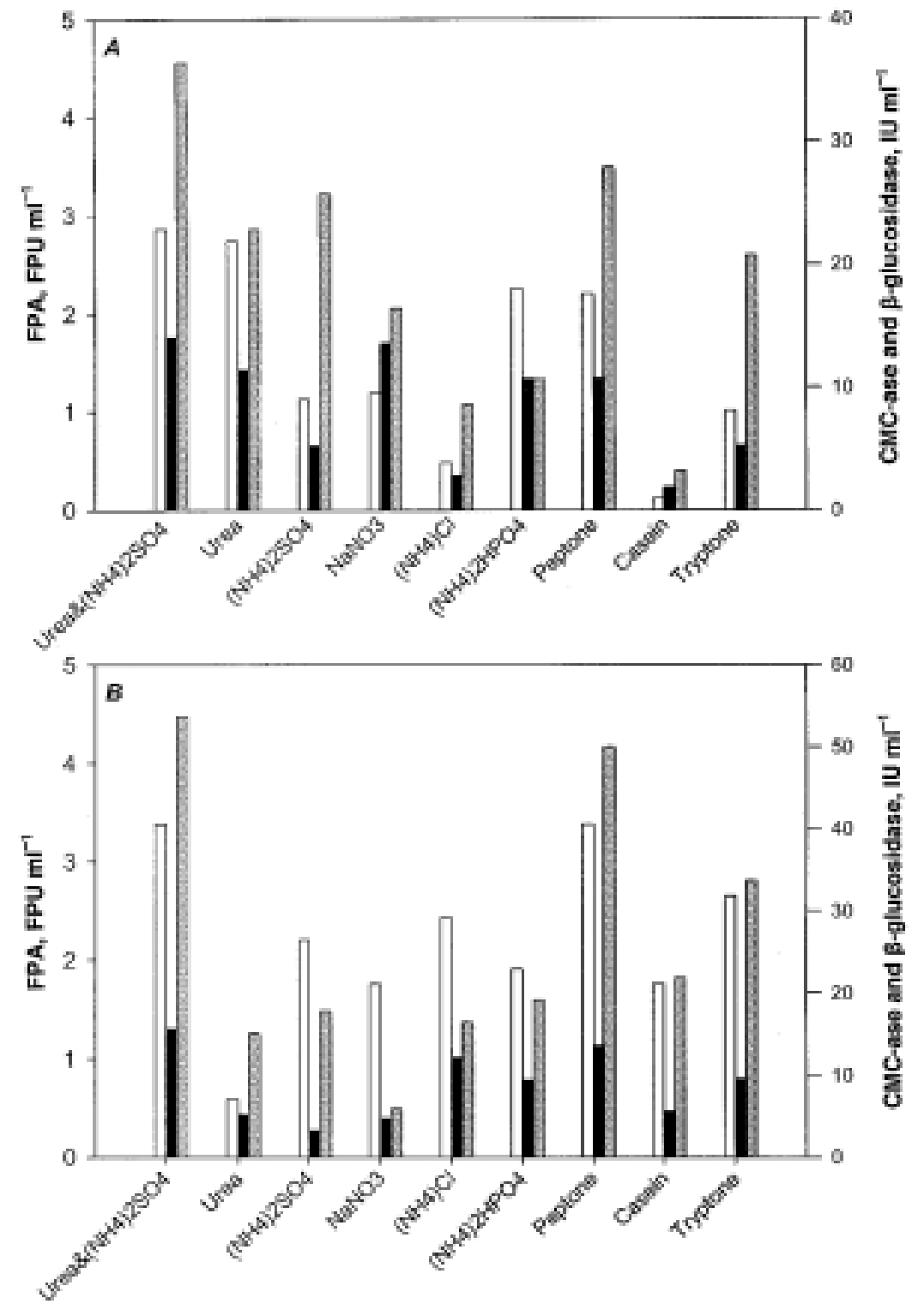

Fig. 1. The effect of nitrogen source on the cellulase production of $T$. koningii using various carbon sources. A: pretreated sugar cane bagasse, B: pretreated rice straw. Filter paper activity (FPA): white bars, $\mathrm{CMC}$-ase activity:black bars, $\beta$-glucosidase activity: grey bars 

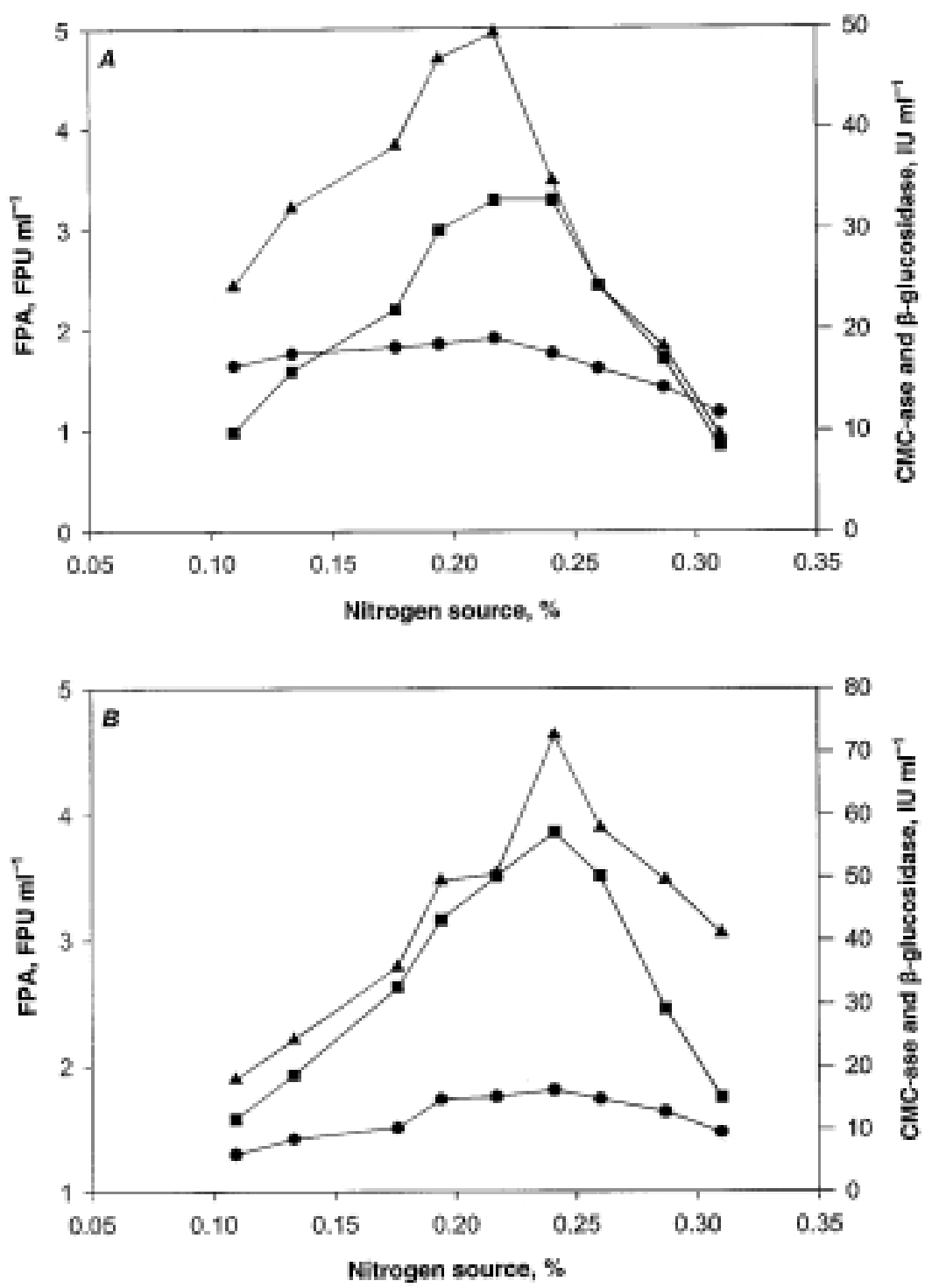

Fig. 2. The effect of nitrogen source concentration on the cellulase production of $T$. koningii using various carbon sources. A: pretreated sugar cane bagasse, B: pretreated rice straw. Filter paper activity (FPA): $\mathbf{\square}, \beta$-glucosidase activity: $\boldsymbol{\Lambda}, \mathrm{CMC}$-ase activity: 
It can be seen that $0.217 \%$ nitrogen from urea and $\left(\mathrm{NH}_{4}\right)_{2} \mathrm{SO}_{4}$ containing medium was optimal for cellulase production by $T$. koningii. However, maximum CMC-ase and $\beta$-glucosidase activities were obtained at a lower nitrogen source concentration (see Fig. 2). At $0.194 \%$ nitrogen concentration, the CMC-ase and $\beta$-glucosidase activities reached $96 \%$ of the activities obtained on the control medium ( $0.217 \%$ nitrogen source). It is clear from Fig. 2/A that applying the original amount of ammonium sulfate $\left(7 \mathrm{~g} \mathrm{l}^{-1}\right.$ ), while increasing the urea from $1.5 \mathrm{~g} \mathrm{l}^{-1}$ to $2.0 \mathrm{~g} \mathrm{l}^{-1}$ (which increase the total nitrogen source concentration from $0.217 \%$ to $0.241 \%$ ) caused the increase in the enzyme production of $T$. koningii by about $11.18 \%$ in the case of FPA. The increase in the CMC-ase due to increasing the amount of urea was about $7.2 \%$, while significantly higher, $42.10 \%$, $\beta$-glucosidase activity was obtained.

These results were in line with WEBB and co-workers (1986) and KHALAF ALLAH and co-workers (1993).

\subsection{The effect of surfactants}

The effect of Tween 40,60, 80 on the cellulase production of $T$. koningii was studied at two different concentrations i.e. 0.1 and $0.5 \%$ surfactant in the culture medium. The results are shown in Fig. 3. The highest enzyme production rates were obtained when $0.5 \%$ Tween 60 was applied in the medium.

The rate of enzyme production of $T$. koningii using acid-steam treated sugar cane bagasse was increased about 1.3 times compared to the control medium, in which there was no surfactant added. However, using acid-steam treated rice straw as the carbon source $0.5 \%$ Tween 80 added to the medium was optimal for cellulase production (see Fig. 3/B).

Cellulase production was $3.43 \%, 2.49 \%$ and $13.24 \%$ higher for FPA, CMC-ase and $\beta$-glucosidase compared to the control medium. The final $\mathrm{pH}$ of the medium was slightly affected by Tween 80 . The effect of Tween 80 on the cellulase production by various fungi was observed by HUNG and co-workers (1988). LONG and KNAPP (1991), and STUTZENBERGER (1987) reported the mechanism of enhancement in the enzyme secretion by Tween. Surfactants can increase the permeability of the cell membrane, facilitating more rapid secretion of extracellular enzymes, which in turn leads to greater enzyme synthesis. 


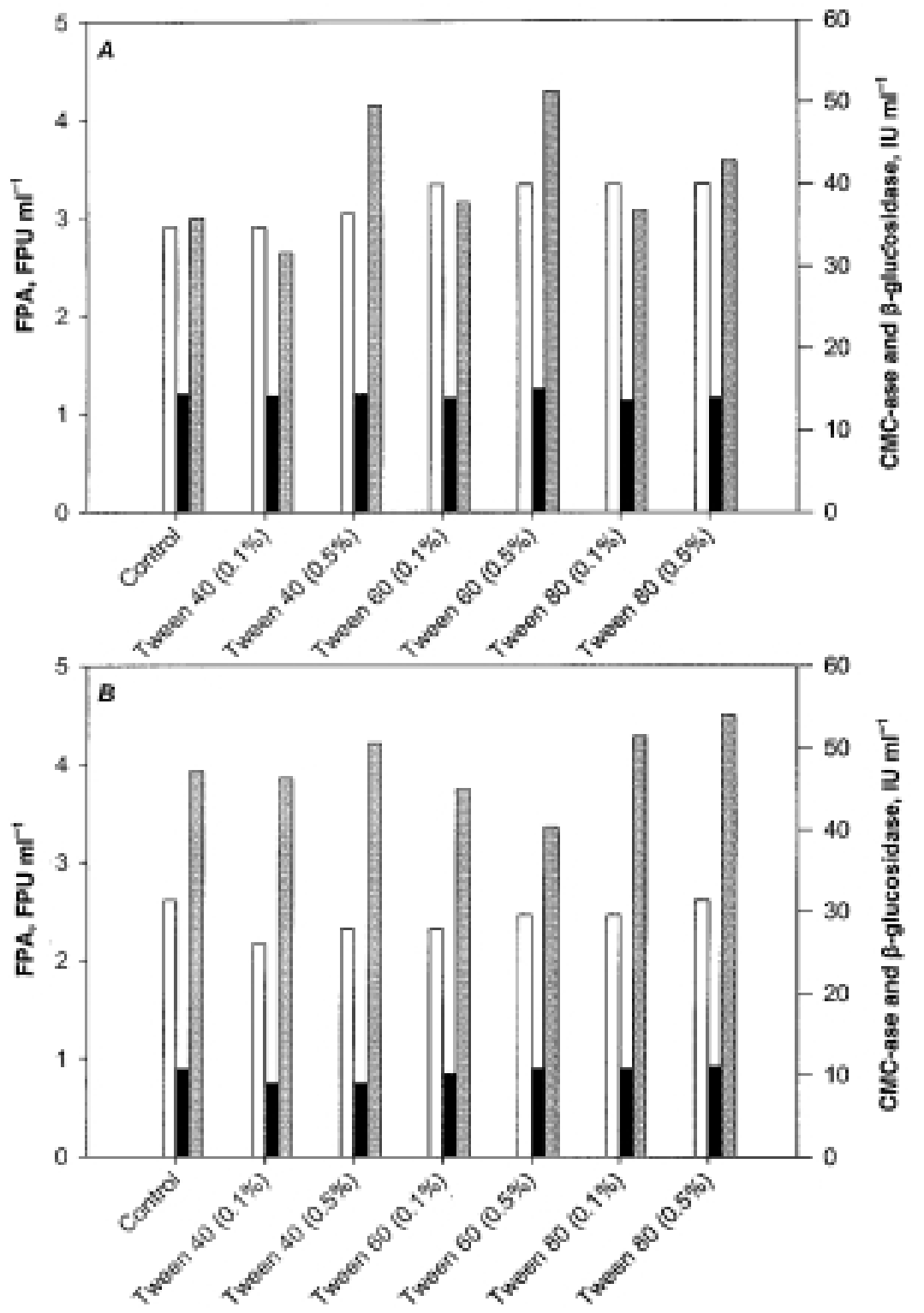

Fig. 3. The effect of surfactants on the cellulase production of $T$. koningii using various carbon sources. A: pretreated sugar cane bagasse, B: pretreated rice straw. Filter paper activity (FPA): white bars, $\mathrm{CMC}$-ase activity: black bars, $\beta$-glucosidase activity: grey bars 

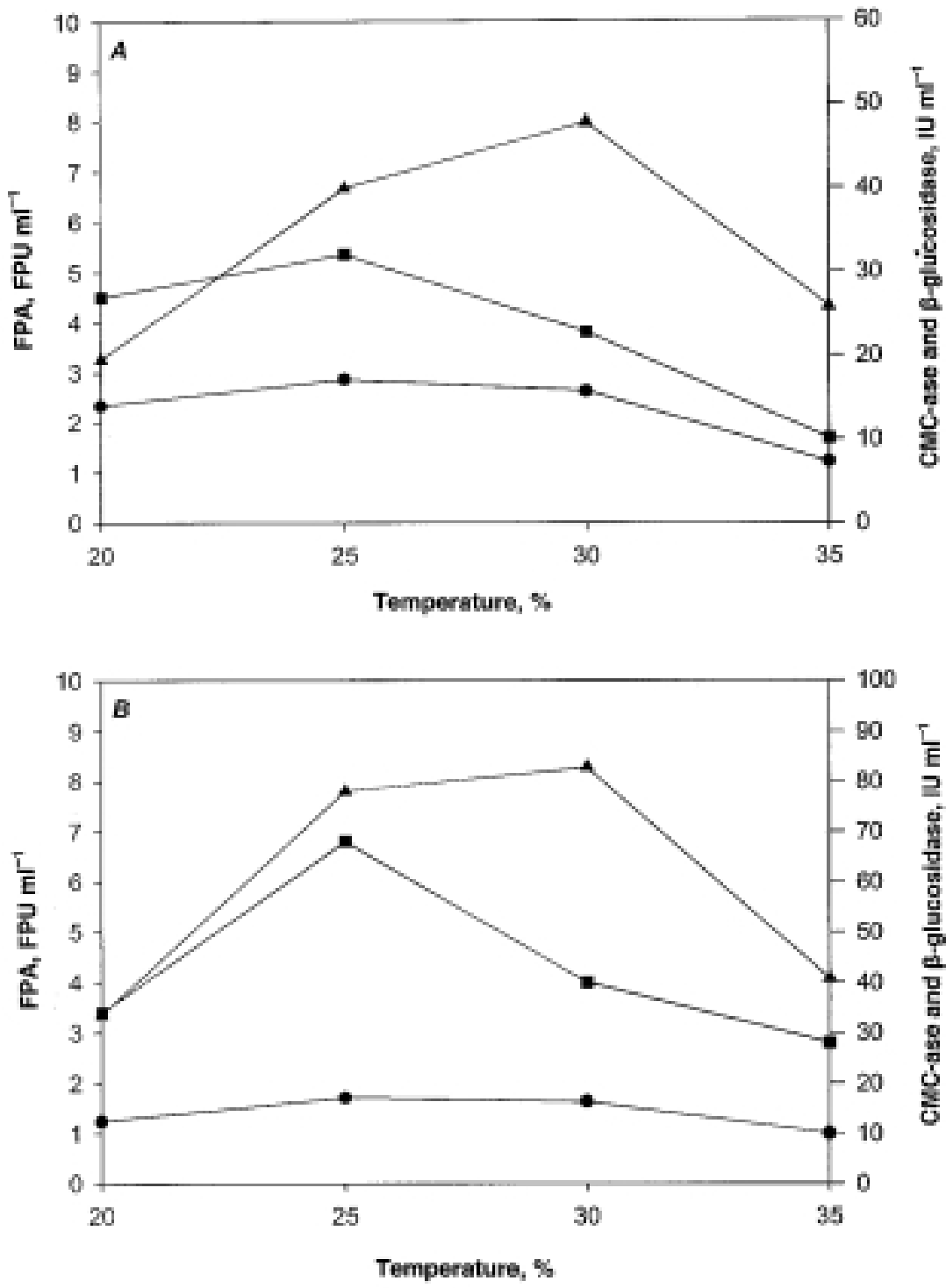

Fig. 4. The effect of incubation temperature on the cellulase production of T. koningii using various carbon sources. A: pretreated sugar cane bagasse, B: pretreated rice straw. Filter paper activity (FPA): $\boldsymbol{\square}, \beta$-glucosidase activity: $\mathbf{\Lambda}, \mathrm{CMC}$-ase activity: $\bullet$ 


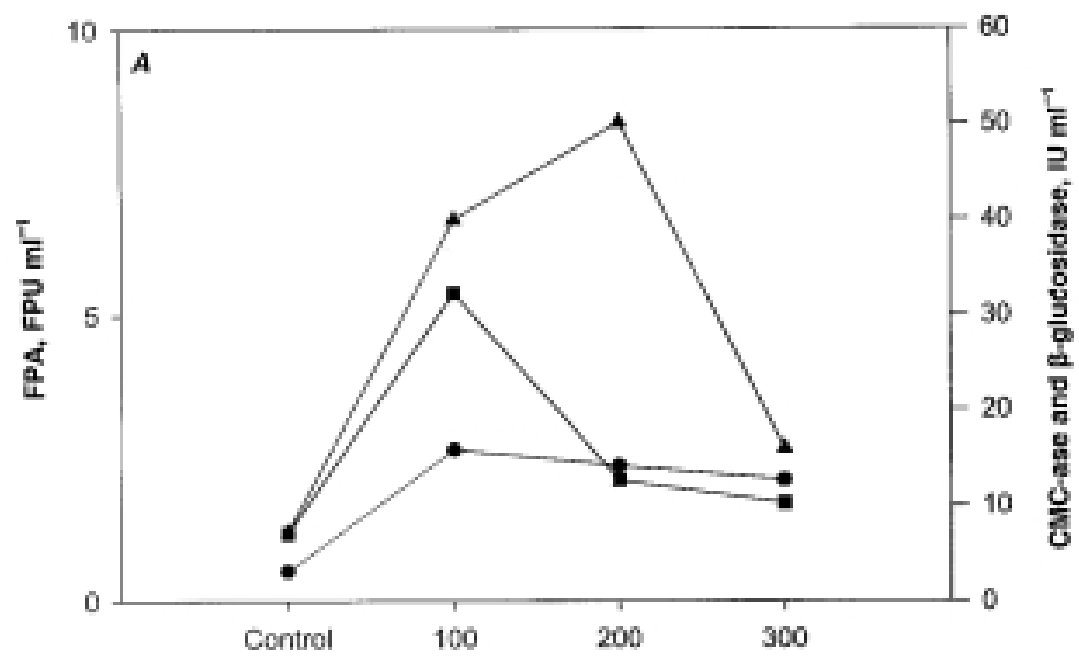

Agitation, r.p.m.

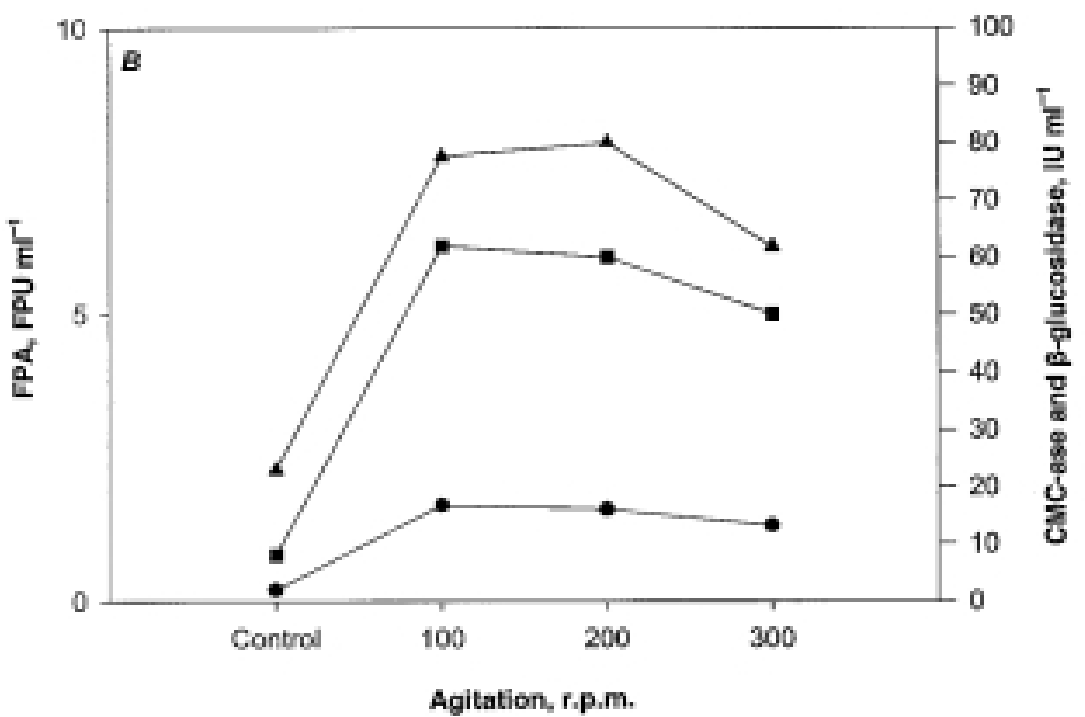

Fig. 5. The effect of agitation on the cellulase production of $T$. koningii using various carbon sources. A: pretreated sugar cane bagasse, B: pretreated rice straw. Filter paper activity (FPA):

$\beta$-glucosidase activity: $\boldsymbol{\Lambda}, \mathrm{CMC}$-ase activity: 


\subsection{The effect of incubation temperature}

To account for the effect of incubation temperature on the cellulase production of T. koningii using two different carbon sources, cultivation was run at 20,25, 30 and $35^{\circ} \mathrm{C}$. The results are shown in Fig. 4. It can be seen that cultivation temperature of $25^{\circ} \mathrm{C}$ was optimal for cellulase production (FPA, and CMC-ase), while $30^{\circ} \mathrm{C}$ was favorable for $\beta$-glucosidase production for both acid-steam treated bagasse and rice straw.

Higher temperature resulted in progressive decline in cellulase production. The enzyme activities obtained at $35{ }^{\circ} \mathrm{C}$ were about $50-60 \%$ lower than that of obtained at $25{ }^{\circ} \mathrm{C}$ using both acid-steam treated bagasse and rice straw as carbon source. These results were in agreement with those obtained by KNAPP and LEGG (1986), DOPPELBAUER and co-workers (1987), BASTAWDE (1992) and CHAUDHURI and SAHAI (1993).

\subsection{The effect of agitation}

The effect of agitation on the cellulase production using two different carbon sources was investigated. The results showed that the enzyme production could be increased with increasing agitation (Fig. 5), however increasing the agitation speed above 100 r.p.m. resulted in a decreased cellulase enzyme production. Although, the FPA and CMC-ase activities were decreased when the agitation speed was increased from 100 to 200 r.p.m, the $\beta$-glucosidase production was increased considerably.

The high concentration of carbon source resulted in increased viscosity of the medium that may affect the availability of oxygen needed for $\beta$-glucosidase production. These results were in agreement with those reported by MAGNELLI and co-workers (1996), Buswell and CHANG (1994), SILVA and co-workers (1995) and RÉCZEY and co-workers (1996).

\section{Conclusions}

Acid-steam pretreatment of both sugar cane bagasse and rice straw proved to be an effective method to increase accessibility for cellulase production with $T$. koningii 2691. Urea and other organic nitrogen compounds were better $\mathrm{N}$-sources than inorganic ammonium containing salts. Supplementing the culture medium with surfactants, such as Tween, increased the cellulase production considerably. The effect of incubation temperature and agitation was also investigated. The results obtained were similar to those of reported earlier using other Trichoderma strains. It can be concluded that T. koningii is an effective cellulase producing microorganism showing good yields of enzymes on both pretreated bagasse and rice straw. 


\section{References}

BASTAWDE, K. B. (1992): Cellulolytic enzymes of thermotolerant Aspergillus terreus strain and their action on cellulosic substrates. World J. Microb. Biotechnol., 8, 45-49.

BuSwEll, J. A. \& CHANG, S. (1994): Biomass and extracellular hydrolytic enzyme production by six mushroom species grown on soybean waste. Biotechnol. Lett., 16, 1317-1322.

CARrasco, J. E., SAiZ, M., NAVArro, A., SORIANO, P., SAFZ, F. \& MARTinEZ, J. M. (1994): Effect of dilute acid and steam explosion pretreatments on the cellulose structure and kinetics of cellulosic fraction hydrolysis by dilute acids in lignocellulosic materials. Appl. Biochem. Biotechnol., 45/46, 23-34.

CHAUDHURI, B. K. \& SAHAI, V. (1993): Production of cellulase using a mutant strain of Trichoderma reesei growing on lactose in batch culture. Appl. Microbiol. Biotechnol., 39, 194-196.

DOPPELBAUER, R., ESTERBAUER, H., STEINER, W., LAFFERTY, R. M. \& STEINMULLER, H. (1987): The use of lignocellulosic wastes for production of cellulase by Trichoderma reesei. Appl. Microbiol. Biotechnol., 26, 485-494.

ENAYATI, N. \& PARULEKAR, S. (1995): Enzymatic saccharification of soybean hull-based materials. Biotechnol. Progress, 11, 708-711.

HAAPAlA, R., LinKO, S., PARKKINEN, E. \& SUOMINEN, P. (1994): Production of endo-1,4- $\beta$-glucanase and xylanase by T. reesei immobilized on polyurethane foam. Biotechnol. Bioeng., 43, 401-406.

HAAPAlA, R., PARKKINEN, E., SuOMINEN, P. \& LinKO, S. (1996): Production of endo-1,4- $\beta$-glucanase and xylanase with nylon-web immobilized. Enzyme microbiol. Technol., 18, 495-501.

Hung, B. R., LarA, L., PAtron, M. A., Ugarava, N. N., BechStedT, W. \& ClapPeS, S. (1988): Tween 80 and proteose peptone effect on cellulase production. Acta Biotechnologica, 8, 461-464.

KHALAF Allah, A. M., ElWAKEIL, F. A. \& El-FANRA, S. A. (1993): Production of cellulase by Aspergillus and Trichoderma sp. on soybean hulls. Res. Bull. Home Econ. Menofiya Univ., 3 (1), 33-34.

KNAPP, J. S. \& LEGG, M. (1986): The effect of different cellulosic growth substrates and $\mathrm{pH}$ on the production of cellulolytic enzymes by Trichoderma reesei. J. appl. Bacteriology, 61, 319-329.

LONG, K. \& KNAPP, J. S. (1991): The effect of Junlon PW110 and Tween 80 on the production of cellulolytic enzymes by Coprinus cinereus. Mycol. Res., 95, 1077-1081.

MAGNElli, P., RAMOS, A. M. \& FORCHIASSIN, F. (1996): Factors influencing cellulase production by Saccobolus saccoboloides. Mycologia, 88, 249-255.

MANDELS, M. (1985): Application of cellulases. Biochem. Soc. Trans., 13, 414-416.

MANDELS, M., ANDREOTTI, R. \& ROCHE, C. (1976): Measurement of saccharifying cellulase. Biotechnol. Bioengng Symp., 6, 21-33.

MANDELS, M. \& WEBER, J. (1969): The production of cellulase. Adv. Chem. Ser., 95, 391.

MiLler, G. L. (1959): Use of dinitrosalicylic acid for determination of reducing sugar. Anal. Chem., 31, $426-428$

RÉCZEY, K. SZENGYEL, Zs., EKLUND, R. \& ZACCHI, G. (1996): Cellulase production by T. reesei. Bioresource Technol., 57, 25-30.

RÉCZEY, K., StAlBrand, H., PreSsOn, L., HANH-HAGERDAl, B. \& TJERneld, F. (1900): Continuous cellobiose hydrolysis using self-immobilized $\beta$-glucosidase from Apergillus phoenicis QM 329 in a fluidized bed reactors. Appl. Biochem. Biotechnol., 24/25, 637-649.

SILVA, S., ELMORE, B. B. \& HUCKABAY, H. K. (1995): Cellulase activity of Trichoderma reesei RUT-C30 on municipal solid waste. Appl. Biochem. Biotechnol., 51/52, 145-153.

STUTZENBERGER, F. J. (1987): Component specific stimulation of cellulase secretion in Thermomonospora curvata by the surfactant Tween 80. J. Appl. Bacteriology, 63, 239-244.

TÜRKER, M. \& MAVITUNA, F. (1987): Production of cellulase by freely suspended and immobilized cells of Trichoderma reesei. Enzyme Microbiol. Technol., 9, 739-743.

WEBB, C., FUKUDA, H. \& ALKINSON, B. (1986): The production of cellulases in a spouted bed fermentor using cells immobilized in biomass support particles. Biotechnol. Bioengng., 28, 41-50. 